\title{
What is the Likely Poverty Impact of the Global Financial Crisis?
}

\author{
Andy Sumner and Sara Wolcott
}

\begin{abstract}
Estimates of the poverty impact of the current crisis are becoming numerous and varied. Global estimates of poverty impacts are based on assumptions regarding Gross Domestic Product (GDP) growth deceleration and the relationship between GDP growth and poverty. We take a different approach. We ask what do we know from research on the poverty impacts of previous financial crises in developing countries? We review current global estimates on poverty and then draw evidence from nine developing countries that have experienced a crisis episode since the mid-1990s.
\end{abstract}

\section{Introduction}

In this article we review the research from previous crises in developing countries on the poverty impacts of crises. This is in order to better estimate and understand the likely poverty impacts of the current global financial crisis. We draw evidence from nine developing countries that have experienced a crisis episode since the mid-1990s.

The article is structured as follows. Section 2 discusses the poverty estimates of the current crisis. Section 3 reviews the research evidence from nine previous country crises. Section 4 concludes.

\section{Estimates of the poverty impacts of the current crisis \\ 2.1 Country-based poverty estimates}

Estimates of the poverty impact of the current crisis are becoming numerous and varied (see below). All suggest the poverty impact will be severe. What is often unclear are underlying assumptions relating to the deceleration of Gross Domestic Product (GDP) growth assumed (and data source and point in time) and additionally, with estimates of the number of new poor, the estimate of the poverty elasticity of GDP growth assumed.

The starting point for global poverty forecasts is growth deceleration data (see Table 1). Using data from the World Bank (Global Economic Prospects published in March 2009), developing countries as a group will experience economic growth in 2008. However, when China and India are excluded, that economic growth falls to zero. In total, the growth deceleration for all developing countries is a GDP growth loss of 4 per cent. This rises to 5 per cent if China and India are excluded.

Over the course of the last six months, various global poverty estimates have been published. Approaches have either been to identify countries or number of the newly poor.

In late 2008, there was a rush to assess which countries were at macroeconomic risk when it became clear the developing countries were not 'decoupled' from the crisis. These forecasts were followed by assessment of countries at risk of a large increase in poverty due to decelerating growth and existing levels of poverty. Cord et al. (2009) argued that of 116 developing countries analysed, 94 had decelerating growth and 43 developing countries were highly exposed to poverty effects of the crisis because of high levels of initial poverty. ${ }^{1}$ The country list included a number of countries with large populations such as Bangladesh, Ethiopia, India, Indonesia, Nigeria, Pakistan and South Africa.

The World Bank (2009b) took a gender lens to poverty impacts and argued that women and

IDS Bulletin Volume 40 Number 5 September 2009 (C) 2009 The Authors. Journal compilation (C) Institute of Development Studies Published by Blackwell Publishing Ltd, 9600 Garsington Road, Oxford OX4 2DQ, UK and 350 Main Street, Malden, MA 02148, USA 


\begin{tabular}{llcccc}
\hline & \multicolumn{3}{c}{$\begin{array}{c}\text { Growth forecast (percentage } \\
\text { change from previous year) }\end{array}$} & \multicolumn{2}{c}{$\begin{array}{c}\text { Deceleration based on } \\
\text { November 2008 } \\
\mathbf{2 0}\end{array}$} \\
& $\mathbf{2 0 0 8}$ & $\mathbf{2 0 0 9}$ & $\mathbf{2 0 1 0}$ & $\mathbf{2 0 0 9}$ & $\mathbf{2 0 1 0}$ \\
\hline Developing countries & 5.8 & 2.1 & 4.4 & -2.3 & -1.6 \\
Latin America & 4.3 & -0.6 & 2.2 & -2.8 & -1.9 \\
South Asia & 5.6 & 3.7 & 6.2 & -1.7 & -1.0 \\
Sub-Saharan Africa & 4.9 & 2.4 & 4.1 & -1.8 & -1.4 \\
Developing countries minus China and India & 4.6 & 0.0 & 2.7 & -2.9 & -2.1 \\
\hline Source World Bank (2009c: 3). & & & & &
\end{tabular}

girls in 33 countries were at high risk of poverty based on the same economic growth deceleration data and existing low gender parity in schooling, and high under-five child mortality deaths. ${ }^{2}$

From these analyses, Cord et al. (2009) then sought to identify which countries were best able to cope with the crisis by considering fiscal and institutional capacities to respond (see

Gottschalk, this IDS Bulletin). Whether countries with higher levels of pre-crisis poverty would be more at risk than those with lower levels is not immediately clear because, for income poverty at least, what matters is the clustering of the nearpoor above the poverty line. This also raises a 'crisis poverty policy dilemma' which is - should policymakers focus attention on the new poor or the existing poor or can both be done?

\subsection{People-based poverty estimates}

Estimating the number of new poor entails not only assumptions about economic growth deceleration but also the relationship between poverty and growth or the poverty elasticity of growth. There was an enormous debate, triggered by Dollar and Kraay's Growth is Good for the Poor in the late 1990s (2002), concerning whether poverty elasticity of growth was one-forone during positive growth episodes and in particular the country variations in the elasticity.

Many of the estimates of the poverty impact of the crisis are based on a poverty elasticity of growth as follows: a 1 per cent declaration of growth raises poverty by 20 million. This figure appears in two World Bank (2008b,c) background notes for the November 2008 G20 and early 2009 press releases (but without explanation). It was also used in the Department for International
Development's (DFID) (2009) estimate that the total number of newly poor would be 90 million as a result of a 4.5 per cent deceleration in GDP growth in developing countries. ${ }^{3}$

In a piece published at the end of April 2009 on the Vox crisis web-blog and carried by the Economist magazine, Chen and Ravallion (2009) revised their estimates of the new poor from 46 to 53 million based on the US $\$ 1.25$ day poverty line, based on taking their pre-crisis data and estimating for 100 countries the poverty impacts. ${ }^{4}$

There are various other figures to ponder: UNESCO (2009) has estimated the impact on the 390 million poor people in sub-Saharan Africa as a per capita fall in income of 20 per cent or $\$ 46.00$ per person. There are also various estimates of increases in non-income dimensions of poverty. For example, infant deaths may be 200,000-400,000 per year higher on average as a 1 per cent fall in GDP growth leads to an additional 1.5 boy infant deaths per 1,000 live births and 7.4 girl infant deaths per 1,000 live births (World Bank 2009a,b).

Where does all this leave us? One might argue that global estimates during the current crisis are more about triggering political action with numbers. How might we get a clearer sense of the likely poverty impacts of this crisis? One option is to consider the existing research on the poverty impacts of previous financial crises across a set of developing countries that have experienced economic crises in recent years. This is what we do in the next sections. 
3 Tracking poverty during an economic crisis 3.1 Methodological issues in crisis poverty impact assessment

To conduct a review of assessments of poverty impacts of crises, several methodological issues arise including the definition of a 'crisis' episode, the criteria for choosing which crises to review, when to assess (the temporal nature of 'waves' of the crisis), the lack of a counterfactual scenario and that the poverty impact of a crisis is a result of pre-crisis and during-crisis policies and the local socioeconomic context. In short, the isolation of poverty impacts of a crisis is problematic. What we can say is exactly what happened and identify indicators that demonstrate the visible dimensions of changes in poverty during a crisis episode.

\section{As Jickling (2008: 1) notes:}

There is no precise definition of financial crisis but a common view is that disruptions in financial markets rise to the level of a crisis when the flow of credit to households and businesses is constrained and the real economy of goods and services is adversely affected.

Often it is rapid falls in exchange rates that are viewed as the key indicators of a crisis and later on GDP contractions. ${ }^{5}$ The Frankel and Rose (1996: 3) definition of a (currency) crisis is often cited in the literature on crises:

[A crisis is a situation whereby there is] a nominal depreciation of the currency of at least 25 per cent that is also a 10 per cent increase in the rate of depreciation.

Time is also an important dimension. There is generally a time lag from the start of a financial crisis to the various impacts on the real economy and on poverty. Changes in GDP growth can take 4-6 quarters from the onset of a financial crisis (Claessens et al. 2008). Baldacci et al. (2002: 7) note a three-year window is usually given for a crisis 'episode'. This might suggest we need to compare data on poverty from the year of or prior to the crisis (pre-crisis) and then two years later (for the peak impacts).

Financial crises historically have three crisis 'waves'. The first 'wave' is financial in nature and visible in changes in the exchange rate and stock market, interest rates, etc. The second wave is when there is transmission from the financial to real sector affecting notably, construction and manufacturing sectors and visible in falls in investment and GDP contraction. The third wave is then the transmission from the real economy (and finance) to visible household level and intra-household level impacts.

Doing social impact assessments amid these variables is tricky. We need to look at how much poverty incidence or severity has risen proportionally, based on consistent time series data (assuming data available is good quality). Ideally, we need a peak-to-trough picture in terms of an inflation spike or GDP contraction. Increasingly, countries conduct mini-surveys during crises with smaller samples such as Indonesia during the 1997/8 crisis but this raises issues of different data from different surveys and their timing at different points in the crisis episode (see Table 2).

There is then the issue of the counter-factual. What would have happened without a crisis? It is very difficult to isolate crisis impacts from factors such as positive impacts of emergency programmes on mitigating poverty impacts. In Indonesia in 1997-9 there was also the El Nino drought, a highly orthodox IMF crisis response (high interest rates, cancellation of infrastructure projects, reduction in fuel and agriculture subsidies, etc.) and a US $\$ 5$ billion social safety net response of subsidised rice, cards for free health services, primary school scholarships and public works employment creation schemes.

With regard to the current crisis, there are also the interlinkages to multiple crises. This includes the 'triple f' crises: the food price hike of early/mid-2008; the fuel prices rises in mid2008 as well as the financial crisis. This is particularly important for poverty given that a large proportion of household budgets of the poor are spent on food and fuel.

In the following review, we take nine developing countries that have experienced a financial crisis in the most recent period of financial globalisation - the early/mid-1990s onwards. We take data from World Development Indicators to ensure some comparability across countries and we refer to the wider literature as and when it is relevant. 
Table 2 Indonesia: survey poverty data available during the $1997 / 8$ crisis

\begin{tabular}{|c|c|c|c|c|}
\hline Surveys & Type & Date and sample size & Sample frame & Interviews \\
\hline $\begin{array}{l}\text { BPS Susenas (Funded } \\
\text { and conducted by BPS) }\end{array}$ & $\begin{array}{l}\text { Random, } \\
\text { longitudinal, } \\
\text { quantitative }\end{array}$ & $\begin{array}{l}\text { Feb. } 1996 \text { and 1999: } \\
\text { 65,000 HH; Dec.1998 } \\
\text { (mini-Susenas) 10,000 HH }\end{array}$ & $\begin{array}{l}\text { Indonesian } \\
\text { population }\end{array}$ & $\begin{array}{l}\text { Head of } \mathrm{HH} \text { and } \\
\text { partner interviewed } \\
\text { by BPS enumerators }\end{array}$ \\
\hline $\begin{array}{l}\text { BPS Sakernas (Funded } \\
\text { and conducted by BPS) }\end{array}$ & $\begin{array}{l}\text { Random, } \\
\text { longitudinal, } \\
\text { quantitative }\end{array}$ & $\begin{array}{l}\text { Aug. 1996, Aug. 1997: } \\
65,000 \mathrm{HH}\end{array}$ & $\begin{array}{l}\text { Indonesian } \\
\text { population }\end{array}$ & $\begin{array}{l}\text { Head of } \mathrm{HH} \text { and } \\
\text { partner interviewed } \\
\text { by BPS enumerators }\end{array}$ \\
\hline $\begin{array}{l}\text { UNICEF } 100 \text { Villages } \\
\text { (Funded by UNICEF/ADB } \\
\text { Conducted by BPS) }\end{array}$ & $\begin{array}{l}\text { Random, } \\
\text { longitudinal, } \\
\text { quantitative }\end{array}$ & $\begin{array}{l}\text { July 1997, Aug. 1998, Dec. } \\
\text { 1998, May 1999: 12,000 HH }\end{array}$ & $\begin{array}{l}120 \mathrm{HHs} \text { in } 100 \\
\text { villages ( } 80 \\
\text { rural and } 20 \\
\text { urban villages) in } \\
10 \text { districts spread } \\
\text { across } 8 \text { provinces }\end{array}$ & $\begin{array}{l}\text { Interviews by } \\
\text { BPS enumerators, } \\
\text { using a modified } \\
\text { version of Susenas } \\
\text { core questionnaire }\end{array}$ \\
\hline $\begin{array}{l}\text { World Bank Kecamatan } \\
\text { (Funded by Ford } \\
\text { Foundation and ASEM } \\
\text { Trust Conducted by BPS) }\end{array}$ & $\begin{array}{l}\text { Non-random, } \\
\text { qualitative }\end{array}$ & $\begin{array}{l}\text { Oct. 1998: 12,075 } \\
\text { 'notables' }\end{array}$ & $\begin{array}{l}3 \text { 'notables' in } \\
4,025 \text { Kecamatans }\end{array}$ & $\begin{array}{l}\text { Questionnaire } \\
\text { consisted of a } \\
\text { standard set and } \\
\text { profession-related } \\
\text { questions. } \\
\text { Respondents also } \\
\text { ranked main crisis- } \\
\text { related problems }\end{array}$ \\
\hline $\begin{array}{l}\text { RAND Indonesian Family } \\
\text { Life Survey (Funded by } \\
\text { USAID and AUSAID } \\
\text { Conducted by RAND } \\
\text { and University Indonesia) }\end{array}$ & $\begin{array}{l}\text { Random, } \\
\text { longitudinal, } \\
\text { quantitative }\end{array}$ & $\begin{array}{l}\text { Aug.-Dec. 1997, Aug.-Dec. } \\
\text { 1998: 1,903 HH }\end{array}$ & $\begin{array}{l}\text { HH selected in } 7 \\
\text { provinces among } \\
\text { IFLS original } 1993 \\
\text { sample, consisting } \\
\text { of } 7,200 \mathrm{HH} \text { in } 13 \\
\text { provinces }\end{array}$ & $\begin{array}{l}\text { HH members } \\
\text { interviewed } \\
\text { separately } \\
\text { by a pair of students. } \\
\text { Tests are performed } \\
\text { by a health worker. }\end{array}$ \\
\hline $\begin{array}{l}\text { Special Education Survey } \\
\text { (Funded and conducted by } \\
\text { Ministry of Education) }\end{array}$ & $\begin{array}{l}\text { Random, } \\
\text { quantitative }\end{array}$ & Oct. 1998: 600 schools & $\begin{array}{l}\text { Five provinces } \\
\text { were chosen and } \\
\text { the sample } \\
\text { stratified to } \\
\text { represent all } \\
\text { Indonesia. }\end{array}$ & $\begin{array}{l}\text { Schools completed } \\
\text { questionnaire }\end{array}$ \\
\hline
\end{tabular}

Source Sumner (2002).

BPS: Biro Pusat Statistik; ADB: Asian Development Bank.

\subsection{Poverty transmission pathways}

In terms of previous crises in developing countries we can identify nine crises since the early 1990s that have been researched (see Table 3). What do we know from these crises on the poverty impacts? We have a reasonable understanding of poverty transmission mechanisms during crises episodes (Baldacci et al. 2002; Lustig and Walton 2009; Pernia and Knowles 1999; Prennushi et al. 1998).

Financial crises impact poverty through several transmission mechanisms. Baldacci et al. (2002) argue that $60-70$ per cent of the poverty impacts of a crisis are due to four factors: unemployment, inflation, reduced public expenditure and GDP contraction.

Prennushi et al. (1998: 1) identified five main types of transmission mechanisms between shocks and welfare as follows: changes in relative prices which lead to changes in relative wages, consumption baskets and employment patterns; changes in aggregate labour demand which can reduce employment levels and/or wage rates; changes in the rates of return on assets; changes 


\section{Box 1 How does a crisis transmit to poverty?}

A crisis may transmit to poverty through the following:

- Changes in labour demand

- Changes in prices

- Changes in public spending

Changes in the value of economic, human, social, environmental and financial assets

Long-term impacts on capabilities (i.e. effects of malnutrition, schooling drop-outs, etc.).

Source Lustig and Walton (2009).

in levels of public transfers, in cash and kind; and changes in community environment, in terms of public health or safety. Lustig and Walton (2009) identify a similar set (see Box 1).

The exact nature of poverty impacts is likely to be a function of: the pre-crisis structure of poverty/vulnerability (notably poverty levels, inequality levels, clustering of people near the poverty line, education, health and economic asset levels, etc.); the pre-crisis social and economic policy package in place (social protection in particular); the nature or type of the financial crises (is it a capital account shock or a banking crisis or a current account shock via trade?); the economic and social policy response to the crisis (social safety nets in particular but also fiscal stimuli and changes in public expenditures); the health of the global economy and finally the actual household responses to the crisis.

Households that are adversely hit may respond by trying to increase income. They may do this via family members seeking new or additional work and/or drawing upon savings, credit (if available) and/or selling assets. Or they may try to reduce household expenditures via changes in quantity and quality of diet or health and children's education costs (see Gottschalk 2004; Lustig and Walton 2009).

Figure 1 Impact on income poverty of selected financial crises, 1990-present

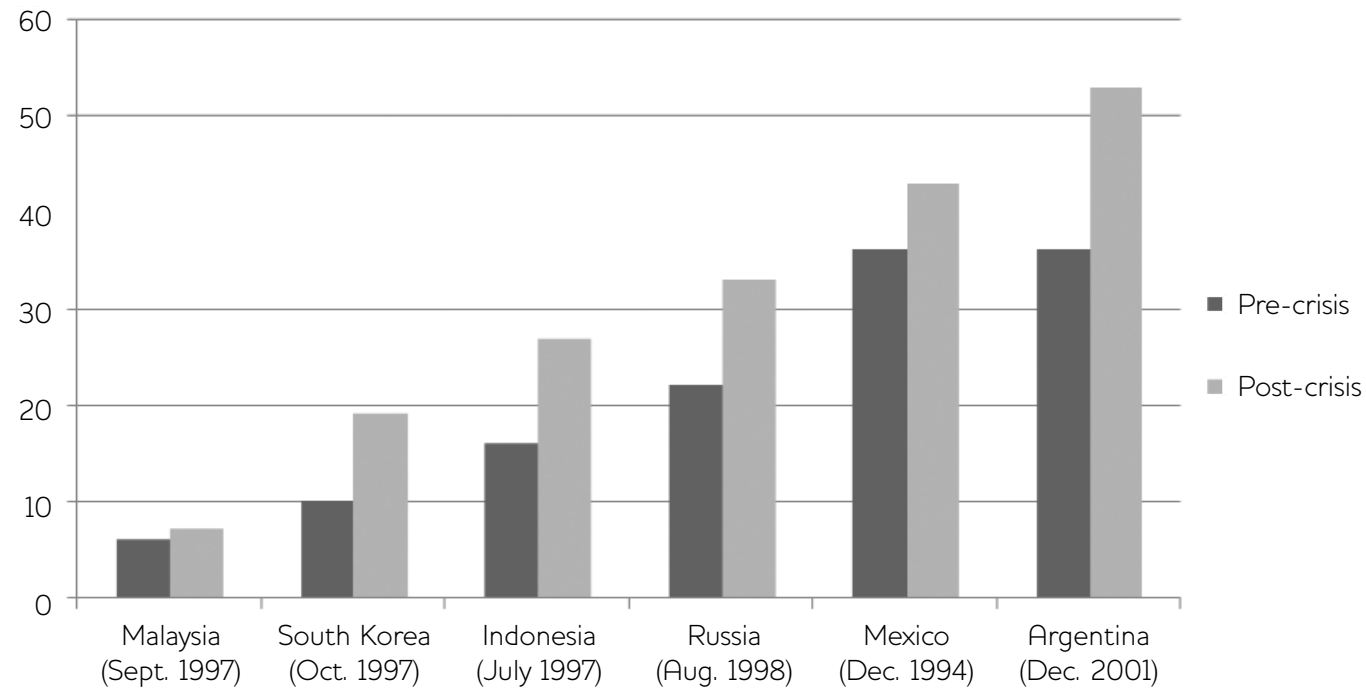

Source Data from Gottschalk (2004: 13). 
Table 3 Impact on national poverty headcount of selected financial crises, 1990-present

\begin{tabular}{|c|c|c|c|c|}
\hline \multirow[t]{2}{*}{$\begin{array}{l}\text { Country } \\
\text { (date crisis began) }\end{array}$} & \multirow[t]{2}{*}{$\begin{array}{l}\text { GDP contraction } \\
\text { (year of crisis) }\end{array}$} & \multirow{2}{*}{$\begin{array}{l}\text { Proportional } \\
\text { change in national } \\
\text { poverty headcount } \\
\text { (\% increase) }\end{array}$} & \multicolumn{2}{|c|}{$\begin{array}{l}\text { Population under national } \\
\text { poverty line (\%, date) }\end{array}$} \\
\hline & & & $\begin{array}{l}\text { Pre-crisis (year } \\
\text { prior to crisis) }\end{array}$ & $\begin{array}{l}\text { Post-crisis } \\
\text { (crisis }+2 \text { years) }\end{array}$ \\
\hline Mexico (Dec. 1994) & -6.2 & 119.4 & 36.0 (1994) & $43.0(1996)$ \\
\hline Thailand (July 1997) & -10.5 & 138.8 & 9.8 (1994) & $13.6(1998)$ \\
\hline Indonesia (July 1997) & -13.1 & 172.6 & $15.7(1996)$ & 27.1 (1999) \\
\hline Malaysia (Sept. 1997) & -7.4 & 114.8 & $6.1(1997)$ & $7.0(1998)$ \\
\hline South Korea (Oct. 1997) & -6.9 & 200.0 & $9.6(1996)$ & 19.2 (1998) \\
\hline Russia (August 1998) & -6.4 & 149.3 & 21.9 (1996) & 32.7 (1998) \\
\hline Brazil (January 1999) & -4.3 & n.a. & $22.0(1998)$ & 21.5 (2003) \\
\hline Turkey (June 2001) & -6.2 & n.a. & 28.3 (1994) & 27.0 (2002) \\
\hline Argentina (Dec. 2001) & -10.9 & 147.2 & 35.8 (2001) & $53.0(2002)$ \\
\hline Average of 9 crises & -8.0 & 148.9 & 20.6 & 27.1 \\
\hline
\end{tabular}

Source IMF International Financial Statistics Database; World Bank World Development Indicators (Dec. 2008). n.a.: not available.

\subsection{Evidence from previous crisis on income poverty impacts}

The total number of poor people is likely to rise dramatically during a crisis if we look at poverty impacts of previous crises (Figure 1; Table 3; World Bank 2008a). However, just how large the poverty increase is, differs considerably across countries. The poverty increase during crises was much higher in Indonesia, South Korea and Russia but much smaller in Malaysia and Mexico (using World Development Indicators data).

Cline (2002) puts the average poverty impact of a crisis at a 7 per cent increase in the poverty headcount per country (this is more or less consistent with the data in Table 3). If we calculate the average proportional increase in the national poverty headcount, we actually come out at 148.9 per cent (i.e. poverty increases by almost 50 per cent on average). However, this ranges from poverty rising to just 115 per cent in Malaysia and 200 per cent in South Korea (incidentally on a similar GDP contraction).

The average GDP contraction across the nine crises is 8.0 per cent, thus the poverty elasticity is slightly less than one for one overall (0.9).
However, the correlation between GDP contraction and increases in poverty is limited.

Cross-country comparisons should of course be treated with some caution here given differing national poverty lines. Indeed, doing poverty impact assessments of crisis episodes raises various methodological issues such as the separation of crisis and non-crisis factors, when to assess and if data is available for peak to crisis trough. Nevertheless, even with these caveats, the increases in income poverty reported are significant in countries with appropriate data points. Further, the poverty increases do not seem to be as closely tied to the magnitude of the GDP contraction as one might expect.

The rise in income poverty reflects changes in real household per capita consumption, real wages and unemployment (see Table 4). The extent of the poverty rise depends at an aggregate level on changes in GDP and income inequality (see Baldacci et al. 2002) and at household level on household characteristics, education and location - some of the poor will be protected by their geographical isolation and poor connectivity with national and global markets (Ravallion 2008; World Bank 2008a). 
Table 4 Changes in real household per capita consumption, real wages and unemployment

\begin{tabular}{|c|c|c|c|}
\hline $\begin{array}{l}\text { Country } \\
\text { (date crisis began) }\end{array}$ & $\begin{array}{l}\text { Change in real } \\
\text { household per capita } \\
\text { consumption }\end{array}$ & Change in real wages & Changes in unemployment \\
\hline Mexico (Dec. 1994) & 25.0 (1994-1996) & $13.5 \%(1995)$ & From $4.2 \%$ in 1994 to 5.7\% in 1995 \\
\hline Thailand (July 1997) & $12.1(1996-1998)$ & $10 \%(1998)$ & From $1.5 \%$ in 1996 to $5.6 \%$ in 1998 \\
\hline Indonesia (July 1997) & 7.4 (1998) & 30-50\% (1998) & $\begin{array}{l}\text { From } 4.7 \% \text { in } 1997 \text { to } 5.5 \% \text { and } 6.4 \% \text { in } 1998 \\
\text { and } 1999 \text {, respectively }\end{array}$ \\
\hline Malaysia (Sept. 1997) & $12.3(1998)$ & na & From $2.4 \%$ in 1997 to $3.0 \%$ in 1998 \\
\hline South Korea (Oct. 1997) & $12.4(1998)$ & $\begin{array}{l}\text { 4.2\% (4th Q, 1997) } \\
\text { and 8.9\% (1st Q, 1998) }\end{array}$ & From 2\% in 1997 to 6.7\% in 1998 \\
\hline Russia (August 1998) & $25.0(1996-1998)$ & $16.8 \%(1998)$ & $\begin{array}{l}\text { From } 10.8 \% \text { in } 1997 \text { to } 11.9 \% \text { and } 13.7 \% \text { in } \\
1998 \text { and } 1999 \text {, respectively }\end{array}$ \\
\hline Brazil (January 1999) & na & na & From $7.8 \%$ in 1997 to $9.6 \%$ in 1999 \\
\hline Turkey (June 2001) & $10.3(2001)$ & na & na \\
\hline Argentina (Dec. 2001) & 23.8 (2001-2002) & na & $21.4 \%$ in May 2002 \\
\hline
\end{tabular}

Source Adapted from Gottschalk (2004: 11-12). na: not available.

\subsection{Inequality and distribution of impacts}

The distributional impacts of crises are highly uneven and income inequality may worsen during a crisis, adding further pressure to poverty levels (Figure 2; Ravallion 2008).
However, in some countries the gini rises and in others it falls (see Figure 2). Further, impacts on the existing poor and the severity of poverty can be more significant than the headcount.

Figure 2 Changes in inequality during selected crises

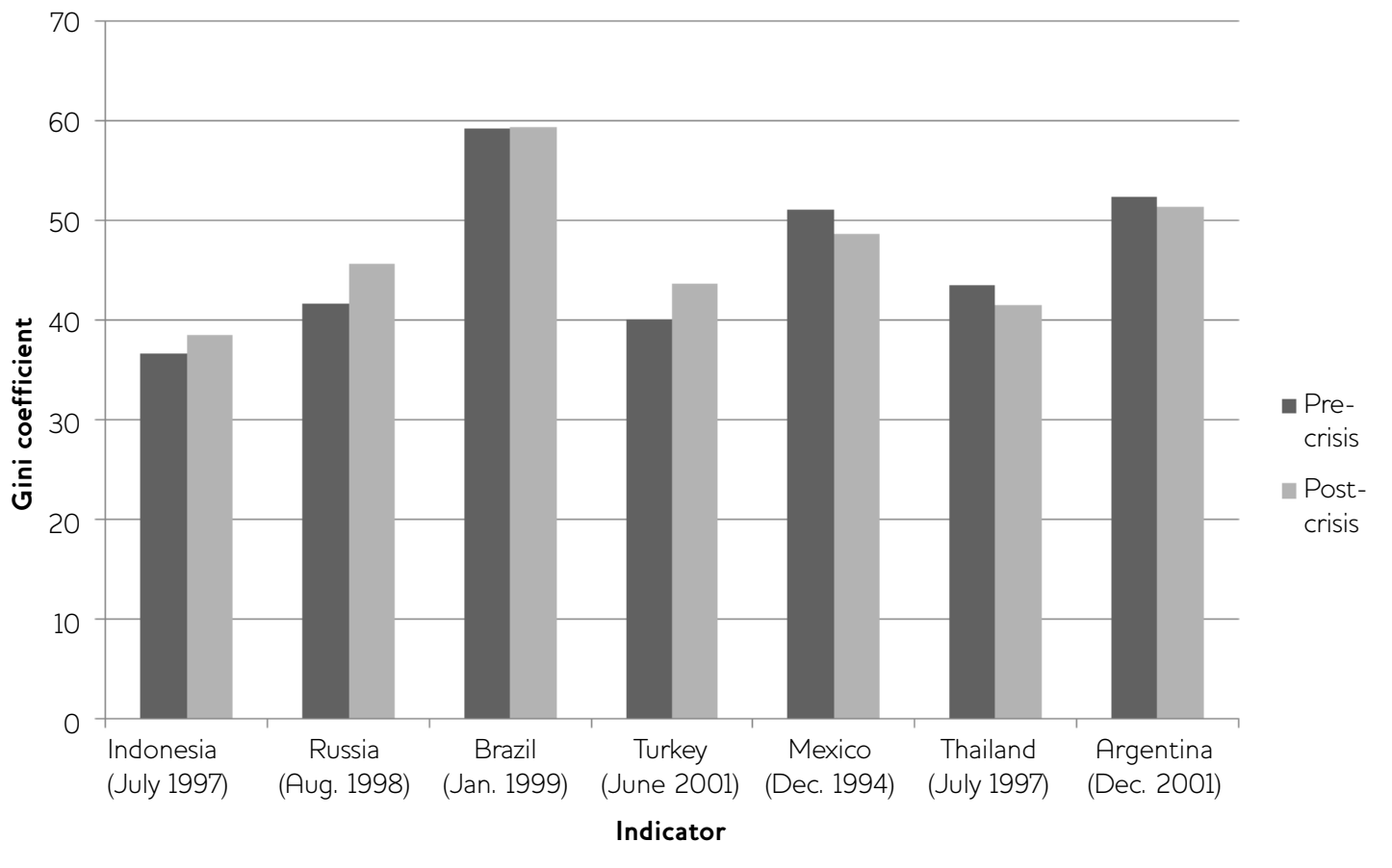




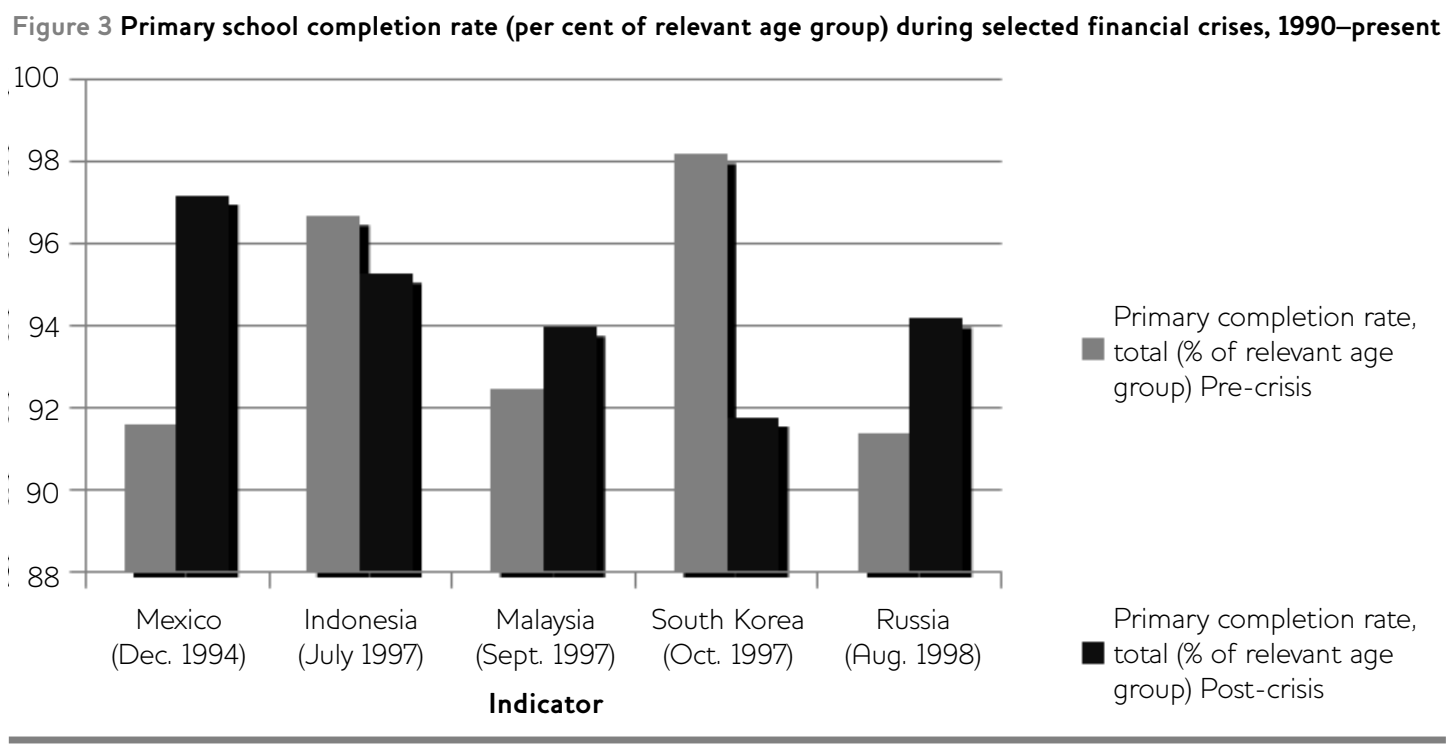

When we consider gender (in)equality, across the nine crises reviewed, gendered impacts are particularly evident via indicators of changes in labour markets (World Bank 1999). It has been argued that women are more likely to lose employment than men, as women dominate export sectors in sectors for garments, electronics and agriculture exports (Buvinic 2009). Further, girls are more likely to drop out of school in both low and middle income countries (Skoufias and Parker 2006; Schady 2004) and girls' infant mortality rates exceed boys' during a downturn (Baird et al. 2007). Elson (2009) identifies four gender biases during crises as follows: a deflationary bias; a privatisation bias; a male breadwinner bias (protect male jobs if possible); a reliance on women to provide safety net bias through paid and unpaid informal work.

Furthermore, during crises, major rural and urban variations are often evident because of different impacts on different production and consumption patterns (World Bank 2008a). However, poverty data from World Development Indicators is limited. The rural poor may be hit harder in the current crisis as falling agriculture export commodity prices reduce rural employment and incomes (IMF 2009: 23). The impacts relate to if the household is a net producer or consumer of food.

\subsection{Non-income poverty impacts}

In our review of nine crises, education health and nutrition indicators generally deteriorated during a crisis episode but not always (see Figures 3 and 4; Table 5). Again, one can ask why does the data show deterioration in some countries but not others?

Research suggests that children are particularly vulnerable during financial crises. A 1 per cent contraction in per capita GDP raises infant mortality between 0.18 and 0.44 deaths per 1,000 children born (Baird et al. 2007). Non-income poverty impacts particularly affect children. Partly, this is because many household coping mechanisms include household decisions related to children such as expenditures on food, education and health (Bhutta et al. 2008; Mendoza 2008). Indeed, there is significant evidence that crisis shocks impact children's future wellbeing and can lead to lesser height, delayed school enrolment and reduced grade completion (Alderman et al. 2006). Further, changes in child labour may be evident (Mok 2009).

A particular concern is that crisis poverty impacts have long-term or inter-generational poverty effects. A negative shock of sufficient size can push households past a 'threshold' or 'tipping point', while the same households can bounce back from a smaller shock (Ravallion 2008). Additionally, there is strong cross-country evidence of psychological distress and mental health problems (Das 2008); elevated levels of community and intra-household conflict during and post-crisis (Friedman and Thomas 2007; World Bank 2008a); and negative environmental 


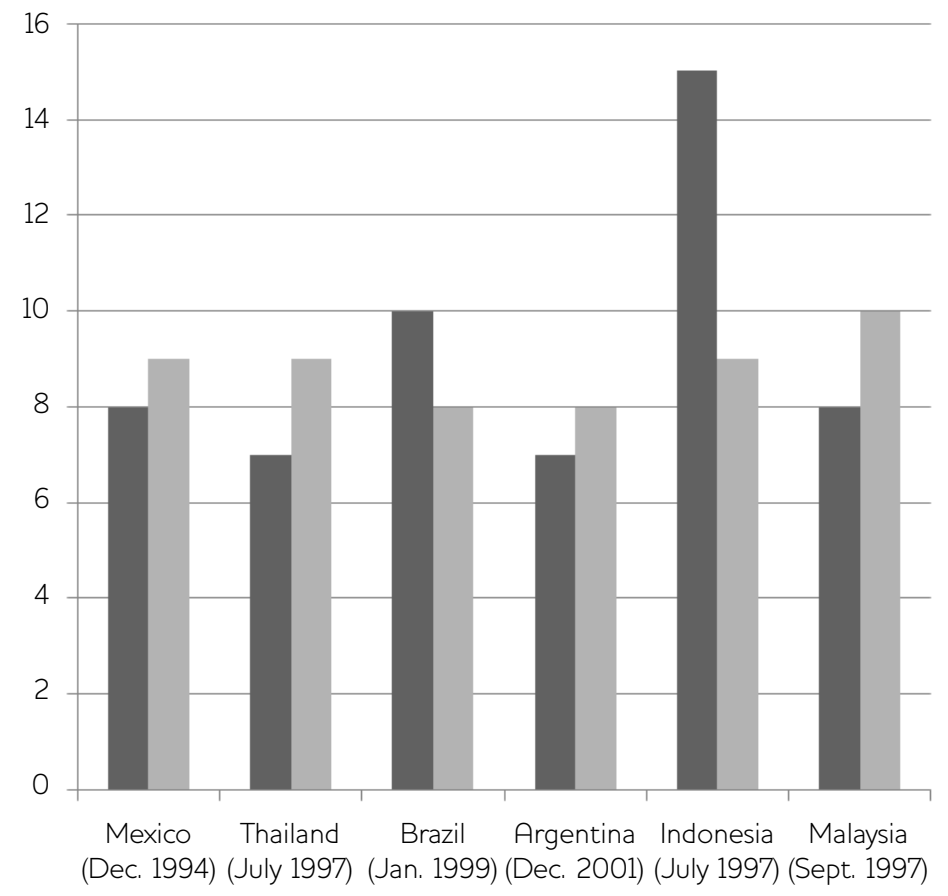

Indicator
Changes in low birth weight babies as \% of all births during selected financial crises 1990-present Pre-crisis

- Changes in low birth weight babies as $\%$ of all births during selected financial crises 1990-present Post-crisis impacts as people are driven to exploit natural resources (Pernia and Knowles 1999).

\section{Conclusions}

What will the likely poverty impact of the crisis be? We know from the nine developing country crises since the mid-1990s that:

- Income poverty rises significantly during all economic crises at approximately the same rate as the GDP contraction on average (but there are considerable variations across countries).

- The distributional impacts of crises are highly uneven. Gendered impacts are particularly evident via changes in labour markets.

- Children are particularly vulnerable to financial crises. This is because many household coping mechanisms include decisions related to children such as expenditures on food, education and health.

Future research needs to ask why crisis poverty impacts differ so much across countries. Why was income poverty increase much higher in Indonesia, South Korea and Russia than Malaysia and Mexico? Why do social indicators deteriorate more in some countries than others? What are the commonalities in countries with higher and lower poverty impacts? Is social protection an important factor, for example?

We need to note that our review here is based on middle-income countries in Asia and Latin

Table 5 Changes in infant mortality in East Asian Crisis, 1997-9

\begin{tabular}{llll}
\hline & GDP growth (\%) & \multicolumn{2}{l}{$\begin{array}{l}\text { Infant mortality rate (per 1,000 live births) } \\
\text { 1995-6 }\end{array}$} \\
\hline Severely affected countries & -22.8 & 50.6 & 58.6 \\
Moderately affected countries & -11.8 & 52.5 & 52.9 \\
\hline Source Bhutta et al. (2008: 7, 23). & & & \\
\hline
\end{tabular}


America. Thus, our understanding of the crisis in low income sub-Saharan Africa is limited. We could review the structural adjustment literature from the early 1980s. However, that was over 25 years ago, and both Africa and the world have changed substantially. Further, the poverty impacts of the current crisis may be worse for poverty impacts because it comes on the tail of food and fuel prices spikes in 2008. Food and fuel account for the majority of poor and near-poor households' consumptions. Households can respond with coping mechanisms such as changes in diet, school enrolments, asset sales and so on but multiple shocks are likely to be much harder to deal with (see Hossain, this IDS Bulletin).

In sum, the April 2009 G20 calls for a global poverty and vulnerability alert are compelling. The G20 Communiqué of April 2009 reads:

... we call on the UN, working with other global institutions, to establish an effective mechanism to monitor the impact of the crisis on the poorest and most vulnerable.

What might such a 'Global Poverty and Vulnerability Alert' look like? National statistical bureaus in a number of countries will be conducting rapid surveys and data also exists from other surveys, notably the UNICEF Multiple Indicator Cluster Surveys (MICs) and World Bank Demographic and Health Surveys (DHS). All these data need to be pooled. However, we also need indicators that better

\section{Notes}

* Correspondence to: a.sumner@ids.ac.uk and s.wolcott@ids.ac.uk

1 This was based on real per capita GDP growth 2008-9 expected to be lower than 2004-7 (using data from the January 2009 IMF World Economic Outlook) and poverty levels $>20$ per cent (based on the 2008 World Development Indicators poverty supplement and a poverty line of US $\$ 1.25 /$ day).

2 This was based on the average for the bottom quartile of countries on each indicator. For gender ratios of primary and secondary school enrolment, this was $<94.6$ and for under-five child mortality the average for the bottom quartile of countries was $<98 / 1,000$.

3 It has proved surprisingly difficult to track down where this 20 million figure originally capture crisis situations. The standard poverty indicators need some adaptation in rapidly changing circumstances. One option is that we expand the MDG-lens to capture increased vulnerabilities due to the crisis by linking poverty indicators to corresponding indicators of vulnerability to poverty. Fortunately, we can build on existing work quickly, while at the same time participatory crisis indicators might also be developed (see Hossain, this IDS Bulletin). For income poverty, the corresponding early warning signal might be the proportion of the population within 10 per cent of the income poverty line. For the education indicators, the early warning signal might be the proportion of the population reporting difficulty paying primary school fees or costs and/or the changes in education costs. Then behind these vulnerability indicators, we could have various sets of indicators relating to the causes of vulnerability to poverty such as social protection and food security, among others (see for such indicators, see Barrientos 2007;

Devereux 2006). Of course, tracking, monitoring and evaluating will not, in and of itself, solve the problems of poverty. These need to be done within a rapid-response context. 'Operation rooms' are needed to allow local-level governments, civil society and aid agencies to respond efficiently and effectively to locallyappropriate responses. If such a Global Poverty and Vulnerability Alert can bring such things together it would play a major role in informing policy interventions which reduce vulnerability and poverty.

comes from. Various Google searches on 'crisis + poverty +20 million' bring up the ILO's October 2008 estimate that the crisis will cost 20 million jobs which was later revised to 33 million (ILO 2009). A possible source is Chen and Ravallion's updated poverty data (2008) which was produced following the availability of new price data in 2008. This article (p. 19) argued that global poverty fell by 500 million over 25 years at a decline in the poverty headcount of 1 per cent per year (implicitly 20 million people per year). However, as they note (p. 10) 'the overall elasticity of the poverty line to mean consumption is about 0.7 '. This would equate 20 million with 0.7 per cent growth on average. Ravallion's earlier study (2004) which was cited in IMF's crisis report (2009) 
argued that the average across countries is 2 per cent but notes that the poverty elasticity of growth varies widely and across countries it varies from 0.6 to 4.3 when using measures of absolute poverty.

\section{References}

Alderman H.; Hoddinott, J. and Kinsey, B. (2006) 'Long-term Consequences of Early Childhood Malnutrition', Oxford Economic Papers 58.3: 450-74

Baird, S.; Friedman, J. and Schady, N. (2007) Aggregate Income Shocks and Infant Mortality in the Developing World, World Bank Working Paper 4346, Washington DC: World Bank

Baldacci, E.; de Mello, L. and Inchauste, G. (2002) Financial Crisis, Poverty and Income Distribution, IMF Working Paper 02/04, Washington DC: International Monetary Fund

Barrientos, A. (2007) Core Analytical Framework and Indicators for the Evaluation of DFID-supported Pilot Social Transfer Schemes, DFID Evaluation Working Paper, London: DFID

Bhutta, Z.; Bawany, F.; Feroze, A. and Rizvi, A. (2008) 'The Impact of Food and Economic Crisis on Child Health and Nutrition', paper prepared for UNICEF conference, New York: UNICEF

Buvinic, M. (2009) 'Impact of Financial Crisis on Women and Families', presentation, Washington DC: World Bank

Chen, S. and Ravallion, M. (2009) The Impact of the Global Financial Crisis on the World's Poorest, www.voxeu.org/index.php?q=node/ 3520 (accessed 30 April 2009)

Ghen, S. and Ravallion, M. (2008) The Developing World is Poorer Than we Thought, but no Less Successful in the Fight Against Poverty, World Bank Policy Research Working Paper 4703, Washington DC: World Bank

Claessens, S.; Kose, M. and Terrones, M. (2008) What Happens During Recessions, Crunches and Busts?, IMF Working Paper 08/274, Washington DC: International Monetary Fund

Cline, W. (2002) Financial Crises and Poverty in Emerging Market Economics, Working Paper 8, Washington DC: Genter for Global Development

Cord, L.; Verhoeven, M.; Blomquist, C. and Rijkers, B. (2009) The Global Economic Crisis: Assessing Vulnerability with a Poverty Lens, Washington DC: World Bank

Das, J. (2008) Mental Health Patterns and Consequences: Results from Survey Data in Five
4 The World Bank's March 2009 paper Swimming Against the Tide, prepared specifically for the G20, used the 46 figure.

5 See for review of definitions Baldacci $e t$ al. (2002: 7).

Developing Countries, World Bank Policy Working Paper 4495, Washington DC: World Bank

Devereux, S. (2006) Strengthening Emergency Needs Assessment Capacity, Brighton: IDS

DFID (2009) Crisis Update - 90 Million to be Pushed into Poverty by 2011, DFID Press Release,

9 March, London: Department for International Development, www.dfid.gov.uk/ news/files/fin-crisis-update lasp (accessed 10 March 2009)

Dollar, D. and Kraay, A. (2002) 'Growth is Good for the Poor', Journal of Economic Growth 7: 195-225

Elson, D. (2009) 'Gender Equality and the Economic Crisis', presentation at the International Development Research Centre/ Society for International Development (IDRC/SID) meeting, Ottawa, 27 November

Frankel, J. and Rose, A. (1996) Currency Crashes in Emerging Markets: Empirical Indicators, Centre for Economic Policy Research Working Paper, London: GEPR

Friedman, J. and Thomas, (2007) Psychological Health Before, During and After an Economic Crisis: Results from Indonesia 1993-2003, Policy Research Working Paper 4386, Washington DC: World Bank

Gottschalk, R. (2004) How Financial Crises Affect the Poor, London: Department for International Development

ILO (2009) Global Employment Trends, Geneva: International Labour Organization

IMF (2009) The Implications of the Global Financial Crisis for Low-Income Countries, Washington DC: International Labour Organization

Jickling, M. (2008) Averting Financial Crisis, Washington DC: Congressional Research Service

Lustig, N. and Walton, M. (2009) Crises and The Poor: A Template for Action, Washington DC: World Bank

Mendoza, R. (2008) Aggregate Shocks, Poor Households and Children: Transmission Channels and Policy Responses, New York: United Nations Children's Fund (UNICEF)

Mok, K. (2009) Impacts of the Economic Crisis on Education, New York: UNICEF 
Pernia, E. and Knowles, J. (1999) Assessing the Social Impact of the Financial Crisis in Asia, Manila: Asian Development Bank

Prennushi, G.; Ferreira, F. and Ravallion, M. (1998) Macroeconomic Crises and Poverty: Transmission Mechanisms and Policy Responses, World Bank Working Paper 2160, Washington DC: World Bank

Ravallion, M. (2008) Bailing out the World's Poorest, World Bank Development Research Group

Policy Research Working Paper 4763, Washington DC: World Bank

Ravallion, M. (2004) Pro-Poor Growth: A Primer, World Bank Policy Research Working Paper 3242, Washington DC: World Bank

Schady, N. (2004) 'Do Macroeconomic Crises Always Slow Human Capital Accumulation?', World Bank Economic Review 18.2: 131-54

Skoufias, E. and Parker, S. (2006) Labour Market Shocks and Their Impacts on Work and Schooling: Evidence from Urban Mexico, IFPRI Discussion Paper 129, Washington DC: IFPRI

Sumner, A. (2002) 'The Social Impact of the 1997/8 Economic Crisis in Indonesia 1997/8', unpublished PhD thesis, London: London South Bank University

UNESCO (2009) Global Crisis Hits World's Most Vulnerable, Press Release, 3 March, Paris:
United Nations Educational Scientific and Cultural Organization

World Bank (2009a) Swimming Against the Tide: How Developing Countries are Coping with the Global Crisis, Washington DC: World Bank

World Bank (2009b) Women in 33 Countries Highly Vulnerable To Financial Crisis Effects, World Bank Press Release 245/PREM, 6 March, Washington DC: World Bank

World Bank (2009c) Global Economic Prospects, Washington DC: World Bank

World Bank (2008a) Lessons from World Bank Research on Financial Crises, World Bank Development Research Group Policy Research Working Paper 4779, Washington DC: World Bank

World Bank (2008b) Global Financial Crisis and Implications for Developing Countries, background paper for G20 Finance Ministers Meeting, Sao Paulo, Brazil, 8 November

World Bank (2008c) Global Financial Crisis: Responding Today, Securing Tomorrow, background paper prepared by the World Bank Group, G20 Summit on Financial Markets and the World Economy, 15 November

World Bank (1999) Gender Dynamics of the East Asian Crisis, Washington DG: World Bank 